\title{
The Willingness of South Africans to Support More Green Reporting
}

\section{C de Villiers}

Department of Accounting, University of Pretoria

\section{ABSTRACT}

The purpose of the article is to establish the willingness of South Africans to support more environmental corporate reporting. A questionnaire was used in the empirical study. The views of three groups were obtained, namely the preparers of financial statements (directors of companies were regarded as such), auditors of financial statements and their users. Seeing that accountability was chosen as the uppermost reason for disclosure in financial statements, the views of users were regarded as most important. However, the views of the other groups may well become more important should environmental legislation or regulation of reporting be considered in fumre. In analysing the results it was found that there were few cases of significant difference of opinion between the three groups. The preparers, auditors and users of financial statements were generally quite positive about more environmental corporate reporting. They were even in favour of making such disclosure compulsory.

\section{INTRODUCTION}

The environment is increasingly discussed at all levels in society. Business enterprises often have a major and visible impact on the environment. They can, therefore, hardly avoid drawing the attention of environmentally concerned individuals and groups to themselves. One of the methods that corporations employ to improve their image is green (or environmental) reporting. Disclosure is, however, still mostly voluntary and without any structure (Bogiages \& Vorster, 1993:53). Shareholders, foreign capital suppliers, government, employees, customers and potential customers as well as the general public all claim a right to 
environmental information (Canadian Institute of Chartered Accountants, 1993:12). The question arises whether green reporting should be increased or whether the starus quo should be maintained.

The question can be answered by determining the willingness of different stakeholder groups to support more green reporting.

\section{REASONS FOR CORPORATIONS TO DISCLOSE GREEN ISSUES}

The reporting of green issues is not necessarily a philanthropic exercise. Nor is it always championed by executives with a particularly soft spot for nature. Apart from any ethical arguments in favour of green reporting, there are also some arguments that make good business sense. For example, the image of the company can benefit from green reporting, which could in turn translate into increased profits.

A number of reasons for green reporting are mentioned by Gray (1993:211). A summary is contained in Table 1 .

The Canadian Institute of Chartered Accountants (1993:3-8) mentions, amongst other things, peer pressure and pressure from the capital markets as further reasons for making environmental disclosures. Peer pressure would be felt if most of the players in a corporation's industry already make disclosures. In such circumstances it may be prudent to conform to industry norms. The capital markets are important to any corporation as a future source of funds, be they in the form of shares or foreign capital. The emergence of ethical investment funds could result in increased disclosure of environmental information to ensure furure access to those funds.

Externalities can be regarded as a reason for environmental reporting. Corporations use natural resources such as fresh air without accounting for the costs involved (Estes, 1976:103). These costs are external to the organization and are paid for by others (Chua, 1990:2). According to Rubenstein (1992:31) the goal of financial statements should be to supply statements which measure the ability of a corporation to produce goods and services after accounting for environmental costs, in order to ensure fairness. 
Table 1: Reasons for Voluntary Disclosure or Non-Disclosure

\section{Disclosure:}

- If not done voluntarily it will become mandatory

- To legitimize current activity

- To distract attention from other areas

- To develop corporate image

- To build up expertise in advance of regulation

- Positive impact on share price

- Reduction of perceived (company or information) risk

- Political benefits

- Competitive advantage

- Shareholders' and other stakeholders' right to know

- To explain expenditure patterns

- The desire to tell people what the company has done/achieved

- Forestall disclosure by other parties

\section{Non-disclosure:}

- Obverse of the above

- No need/motivation to do so

- Wait and see

- Cost

- Data availability (and related costs)

- Secrecy

- Absence of demand for the information

- Absence of a legal requirement

- Never thought of it

- Prioritizing areas for disclosure

Source: Gray, 1993:211 
Amongst the many reasons mentioned and alluded to, accountability is chosen as the most imponant reason for environmental reporting in this paper. Accountability is suggested in Table 1 by the item of "shareholders" and other stakeholders "right to know".

According to the accounting framework of the International Accounting Standards Committee (also adopted by the South African accounting profession), the aim of financial statements is to provide information regarding the "financial position, performance and the changes in the financial position" of a firm (South African Institute of Chartered Accountants, 1990:12). This information should be useful to a range of users for the purpose of economic decision-making.

Financial statements will not necessarily reflect non-financial information (SAICA, 1990:13). Accountability is also mentioned in the accounting framework as part of the purpose of financial statements (SAICA, 1990:14). Management has to account for the resources under its control.

ljiri (1975:32-3; 1983:75-81), Gray, Owen \& Maunders (1987) and Gray (1994:1-51) have proposed that the concept of accountability be used as the basis for an accounting theory. Another influential report that mentioned accountability was the Corporate Report of the Institute of Chartered Accountants in England and Wales (1975:15).

Accountability theory is similar to agency theory, seeing that principals and agents are also central to it. However, whereas agency theory concentrates on the selfish nature of individuals and the resultant agency costs, accountability theory emphasizes the information rights of principals (Gray, 1994:28). The nomal principal and agent relationships envisaged in a corporation would be those between the shareholders and the directors as well as between the directors and the managers. Gray (1994:28), however, proposes an extension to acknowledge the fact that there are also other stakeholders in corporations apart from shareholders. Gray (1994:26) argues that accountability theory is, therefore, able to cater for all accounting, not just the financial variety.

Accountability theory thus suggests that the purpose of accounting is for managers to account to all stakeholders for the management of the resources under their control. This view is in line with the accounting framework, although only as far as information is useful for economic decision-making. Tozer (1992:22) and Sandborg (1993:57) concur that the preparers of financial statements must incorporate a social-environmental dimension to achieve the degree of accountability increasingly demanded. 


\section{GREEN REPORTING PRACTICES IN SOUTH AFRICA}

There are no laws or rules specifically dealing with green reporting in South Africa (Rabie, 1992:83). Of course, generally accepted accounting practice (GAMP) does call for green reporting in certain circumstances, for instance, in the case of contingent liabilities, where the contingency may be of an environmental nature. However, many companies report more than the GAMP requirements. A number of studies have been done on the green reporting found in annual financial statements. Amongst others, there is an annual snudy by the University of Pretoria. As can be expected from a situation of voluntary reporting on potentially sensitive issues, the reporting is mostly in the form of general declarative statements, with no assurance that bad news will ever be published (Savage, 1994:3).

Several surveys have been undertaken to determine the level of environmental reporting by the South African business community. Some rypical results are:

- In a study by Clulow (1991:107), $60 \%$ of the companies in the survey made no mention whatsoever of the environment in their annual financial statements.

- In a study by Savage (1994:3), $63 \%$ of the companies in the survey did mention the environment in some form or other.

- In a study by Steyn and Vorster (1994:24), only 10\% of the companies in the survey disclosed their environmental objectives.

Savage (1994:3) notes that environmental reporting "tends to be ... partial and unsystematic". Bogiages and Vorster (1993:53) conclude that, although environmental reporting could be regarded as limited in the annual reports of European and US companies, South African companies even lag behind the practice in those countries. Although environmental reporting is on the increase, according to Steyn and Vorster (1994:44), it can still not be regarded as satisfactory. 


\section{RESEARCH METHODOLOGY}

\section{Introduction}

The aim of the present study was to establish the willingness of individuals of different stakeholder groups to support more comprehensive environmental corporate reporting. This was established with the use of a questionnaire.

The development of the questionnaire is discussed below, as well as its method of distribution and the population. The response rate and the representativeness of the results are then also discussed.

\section{Questionnaire content}

One of the important objectives in the empirical study was to ensure a high, response rate. It was felt that the length of the questionnaire should be limited to ensure this. The questionnaire was, therefore, limited to just 11 questions (refer to Appendix A).

In the empirical study, $40 \%$ of the questionnaires sent out in the user group were addressed to accountants. However, two questions were included in the survey to establish whether the accountants could justifiably be classified as users. These questions related to whether they are employees of companies and whether they own shares in companies.

The questions in the main section of the questionnaire were based on a questionnaire used in a study by De Villiers and Vorster (1995:44-66). The questions in that survey were based on the recommendations of the United Nations, the Canadian Institute of Chartered Accountants and the Institute of Chartered Accountants of England and Wales (De Villiers \& Vorster, 1995:5154). The De Villiers and Vorster study had certain shortcomings that were corrected in the current survey. However, the questions in the current survey used the same wording in order to ensure comparability. Table 2 gives an indication of which of the three institutions recommended the different kinds of disclosures listed in the survey. 


\begin{tabular}{|c|c|c|c|}
\hline \multirow{2}{*}{$\begin{array}{l}\text { Table 2: } \\
\text { Question }\end{array}$} & \multicolumn{3}{|c|}{$\begin{array}{l}\text { Which Institution Recommended each Type of Disclosure in the } \\
\text { Questionnaire }\end{array}$} \\
\hline & $\begin{array}{l}\text { United Nations } \\
\text { reference }\end{array}$ & $\begin{array}{l}\text { CICA } \\
\text { reference }\end{array}$ & $\begin{array}{l}\text { ICAEW } \\
\text { reference }\end{array}$ \\
\hline $6 a$ & 1991, p.19 & 1993, p.19 & 1992, p.41 \\
\hline $6 \mathrm{~b}$ & 1991 , p.19 & 1993, p.19 & 1992, p.37 \\
\hline $6 c$ & 1991 , p.19 & 1993, p.19 & 1992, p.47 \\
\hline $6 d$ & 1991 , p.19 & 1993, p. 20 & 1992, p.46 \\
\hline $6 e$ & 1991 , p.20 & 1993, p. 19 & 1992, p.50 \\
\hline $6 f$ & & 1993, p.20 & 1992, p. 44 \\
\hline
\end{tabular}

Distribution of the questionnaire

The questionnaires were distributed to the survey sample during October 1995.

The covering letter, the questionnaire (refer to Appendix A) and a window envelope for returning the response were sent out. The questionnaire was reproduced on the back of the covering letter.

The same package, but with the message "SECOND REQUEST" printed in bold lettering on the covering letter, was sent out during November 1995 to the members of the sample from whom no response had been received by that time.

\section{Population}

\section{Introduction}

It was assumed that follow-up action would have to be taken to ensure a high response rate. Record was, therefore, kept of who responded to the survey.

In order to ensure that it would be practical to follow-up the questionnaire, sample sizes were to be kept to a minimum. To ensure that the sample sizes would still yield useful information, the relevant statistical measure considered was 
the coefficient of variation of the mean. A coefficient below $10 \%$ was regarded as acceptable. The responses of the sample must be known as well as the number of points on the scale. The responses were not known at the planning stage and, therefore, the worst-case scenario was assumed. This would entail half the respondents answering at the one end of the scale, with the other half responding at the other end. With a sample size of 50 and a five-point scale, this still yielded a coefficient of variation of below $10 \%$. It was, therefore, decided to limit the sample sizes to 50 for each of the three groups (preparers, auditors and users).

\section{Managers}

The directors of companies listed on the Johannesburg Stock Exchange (JSE) were regarded as the population of managers.

The 50 directors were chosen from the JSE Handbook of September 1995 to February 1996. A total of 655 companies are listed. The companies are listed in alphabetical order. A random sequential sample would therefore approximate a random sample. A random sequential sample of 50 companies was, therefore, taken. One director was then chosen from each of the companies on a random basis.

\section{Auditors}

A list of members as at 30 June 1995 was obtained from the South African Institute of Chartered Accountants. The list was in alphabetical order. The members' names and postal addresses were on the list, with an indication if the member was a resident of a country other than South Africa. Non-residents were excluded from the sample.

The list of members had 15519 names. Because the names were in alphabetical order and there was no pattern of occurrences in the order of the names, a random sequential sample would again approximate a random sample. Fifty names were, therefore, selected on a random sequential basis.

The following four subgroups represent the users of information : 
Chartered Accountants not registered with the Public Accountants and Auditors Board

The 20 names were drawn from the same list of South African Institute of Charered Accountants members mentioned in the section entitled Auditors. The sample was drawn on a random sequential basis in such a way that the names were distributed throughout the list.

\section{Stockbrokers}

The 20 names were drawn from the JSE Handbook of September 1995 to February 1996. A total of 356 partners of the various stockbroker firms are listed. The full list of partners is given in each city where the partnership has offices. After the elimination of duplications, a random sequential sample of partners was selected.

\section{Bankers}

The five banks were personally identified. The names of corporate managers at these banks were obtained by telephone.

\section{Assurance company portfolio managers}

The five assurance companies were personally identified. The names of portfolio managers at these assurance companies were again obtained by telephone.

\section{Summary}

A summary of the various groups and the sample sizes is contained in Table 3 in the following section.

\section{RESULTS OF THE EMPIRICAL STUDY}

There might be bias in the responses to a postal survey because of the tendency of individuals who are knowledgeable or enthusiastic about a particular subject, to respond to a questionnaire on that subject. By the same reasoning, less knowledgeable or enthusiastic individuals may not be inclined to respond. It was in fact possible to find out what the responses of non-respondents might have been, 
because a record was kept of those who responded and who did not. The method is explained in the following section.

\begin{tabular}{|c|c|c|c|c|}
\hline \multicolumn{5}{|c|}{ Table 3: Summary of Mailings and Respondents } \\
\hline Population & Mailed to & $\begin{array}{l}\text { Respon- } \\
\text { dents }\end{array}$ & $\begin{array}{l}\text { Response } \\
\text { rate }\end{array}$ & \\
\hline Managers & \pm 4000 & 50 & 15 & $30 \%$ \\
\hline Auditors & \pm 5000 & 50 & 19 & $38 \%$ \\
\hline $\begin{array}{c}\text { Users } \pm 9500 \\
\text { of which: }\end{array}$ & 50 & 19 & $38 \%$ & \\
\hline Chartered Accs. & \pm 9000 & 20 & 4 & $20 \%$ \\
\hline Stockbrokers & 356 & 20 & 5 & $25 \%$ \\
\hline Banks & 62 & 5 & 5 & $100 \%$ \\
\hline Assurance Cos. & 20 & 5 & 5 & $100 \%$ \\
\hline Totals & \pm 18500 & 150 & $\mathbf{5 3}$ & $35 \%$ \\
\hline
\end{tabular}

\section{Possible Bias}

\section{Managers and Auditors}

In order to determine whether the respondents and the non-respondents agreed or disagreed on the issues raised in the questionnaire, a random sample of 5 nonrespondents was selected from the auditor group and 5 from the manager group. An effort was made to obtain the answers of the 10 individuals chosen in this way. It proved, however, impossible to get hold of one auditor and one manager. This does not influence the bias of the group whose opinions were obtained in this way. The fact that it was not possible to get hold of someone has no bearing on his/her opinions regarding environmental reporing. The 8 responses that were obtained by telephone can, therefore, be regarded as representative of the non-respondents in the auditor and manager groups. 
The aggregate of the auditor and manager responses received by mail was now compared to the aggregate of the auditor and manager responses obtained by telephone for each question. The number of respondents was too small to rely on a chi-squared test. Fisher's exact test at the 5\% level was therefore regarded as an indication of the significance in difference between the two. The tests in fact indicated no significant differences between the mailed and the telephone responses.

The final sample, therefore, consisted of the responses received by mail and those obtained afterwards telephonically. In the case of auditors, this amounted to $(19+4) 23$ and in the case of managers $(15+4) 19$ cases.

\section{Users}

The responses in the user group consisted of 9 received by mail from a total of 40 sent out as well as 10 responses solicited on the telephone. The telephone respondents were identified by asking the receptionist at predetermined organizations to put the researcher through to someone with a specific job-title. In the case of banks this was a manager dealing with corporate clients, and in the case of life assurers a portfolio manager. A response was obtained from each individual so identified. In other words, no one refused to co-operate. It is, therefore, assumed that the responses by telephone would be a good indication of the answers that might have been obtained had all 40 of the mailed questionnaires been completed and returned.

The 9 mailed responses were compared with the 10 telephone responses using Fisher's exact test at the $5 \%$ level. This indicated that there were only two instances of significant difference, namely in questions 2 and $6 \mathrm{~b}$.

For questions 2 and $6 \mathrm{~b}$, the final sample, therefore, consisted of the responses received by mail and those obtained afterwards on the telephone. The telephone responses are regarded as representative of the $(40-9) 31$ non-respondents in the user group. Therefore, the telephone responses were multiplied by (31/10) 3.1. The result was added to the mail and the telephone responses. These numbers were then multiplied by 19 and divided by 50 to arrive at the final result. The total respondents (users) for these two questions would, therefore, still seem to be 19 , although this is the result of a transformed total.

For the questions other than 2 and $6 \mathrm{~b}$, the final sample consisted of the responses received by mail and those obtained afterwards by telephone. This gave a sample size of 19 . 


\section{Final number of respondents}

The final number of respondents is summarized in Table 4 below.

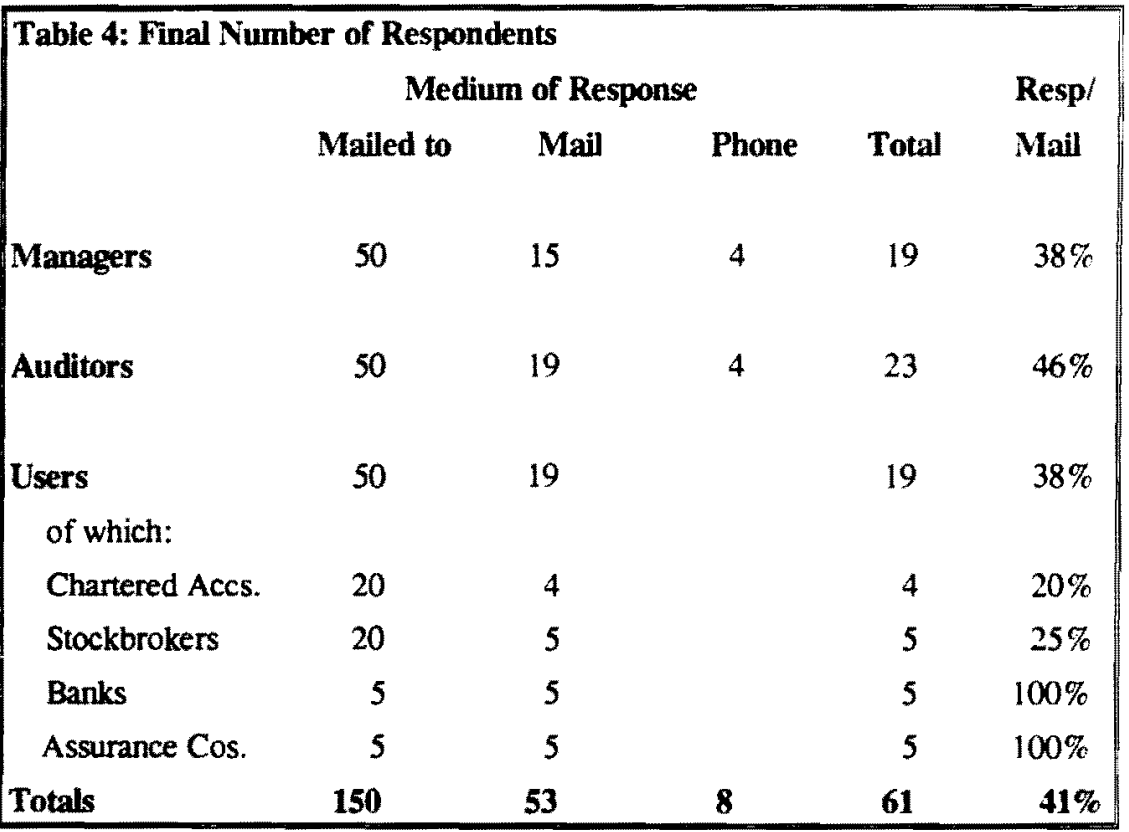

Representativeness of the Results

In the section discussing population, the appropriate sample size was mentioned. The coefficient of variation of the mean actually calculated was found to be below $10 \%$ in all cases. The sample is, therefore, assumed to be representative of the population.

Responses to the questions in the study

The differences between the responses of the three groups (managers, auditors and users) were analyzed by way of Fisher's exact test of significance at the $5 \%$ level. The chi-squared test was not deemed appropriate because of the small number of 
respondents. Where significant differences (at the $5 \%$ level) were found, the fact is mentioned directly after the display of the full results.

The purpose of the questions in this section was to ensure that the Chartered Accountants (SA) in the user group can justifiably be called users.

Do you own shares in a company?

$50 \%$ answered yes.

Are you an employee of a company?

$100 \%$ answered yes.

According to the definition of users in the accounting framework (SAICA, 1990:09), shareholders, employees and customers are, inter alia, users of financial statements. The accountants in the user group who responded are all employees of companies, and half of them also own shares in a company. It would also be safe to assume that they are all customers of companies.

Main section: willingness to support more comprehensive disclosure in the annual report

The purpose of the questions in the main section was to establish the willingness of individuals to support more comprehensive environmental corporate reporting in the annual financial statements.

The answers to the questions were given on a five-point scale. The possibilities were "strongly agree", "agree", "uncertain or does not matter", "disagree" and "strongly disagree".

The responses in the main section of the questionnaire were measured in two ways. Firstly, an average score was calculated for each of the three groups. This was done on the basis of a score of 5 for strongly agree, 4 for agree, 3 for uncertain/does not matter, 2 for disagree and 1 for strongly disagree.

An average score of 3 would therefore indicate no specific preference. An average of above 3 would indicate agreement and below 3 disagreement. The questions were set in such a way that agreement would indicate a willingness to support more comprehensive environmental corporate disclosure. 
The second measure used was that of percentage agreement. The number of respondents who "strongly agreed" and those who "agreed" were expressed as a percentage of all questionnaires returned in the particular group.

A particular question with many "uncertain" respondents could therefore have an average score of more than 3 , but a percentage agreement below $50 \%$. An average of more than 3 can be regarded as agreement by a group, but a percentage agreement of $50 \%$ or more is a very strong indication of agreement.

The averages of the responses and the percentages agreed for each of the questions and each of the stakeholder groups (managers, auditors and users) are given in Table 5. 
Table 5: Summary of Research Results

\begin{tabular}{|c|c|c|c|c|c|c|c|}
\hline & & Managers & Managers & Auditors & Auditors & Users & Users \\
\hline \multicolumn{2}{|c|}{ Environmental Disclosure } & Average & \% positive & Average & $\%$ positive & Average & \% positive \\
\hline 1 & More disclosure voluntary & 4.2 & 89 & 4.0 & 78 & 4.0 & \\
\hline 2 & More disclosure compulsory & 3.5 & 58 & 3.3 & 57 & 4.1 & 90 \\
\hline 3 & Part of annual statements & 3.9 & 84 & 3.6 & 70 & 4.2 & 89 \\
\hline 4 & More financial information & 3.8 & 74 & 3.9 & 78 & 41 & 79 \\
\hline 5 & More non-financial info & 3.9 & 89 & 3.8 & 74 & 4.2 & 89 \\
\hline \multicolumn{8}{|c|}{ Specific Disclosure } \\
\hline $6 a$ & Overview of risks/impacts & 4.1 & 89 & 4.1 & 87 & 4.5 & 100 \\
\hline $6 b$ & Environmental policy & 4.3 & 95 & 4.0 & 87 & 4.0 & 84 \\
\hline $6 c$ & Measurable targets & 3.7 & 63 & 3.7 & 74 & 4.0 & 74 \\
\hline $6 d$ & Performance on targets & 3.7 & 68 & 3.8 & 78 & 3.9 & 74 \\
\hline $6 e$ & Environmental cosis & 3.7 & 74 & 3.6 & 74 & 4.0 & 79 \\
\hline $6 f$ & Environmental audit & 3.2 & 37 & 3.4 & 57 & 4.0 & 84 \\
\hline
\end{tabular}

In the average column, 3 would indicate no preference, whereas 5 would indicate that everyone answered "strongly agree" 


\section{Discussion of the results}

For each of the 11 questions, the difference in the responses between the groups was compared by way of Fisher's exact test at the $5 \%$ level. Significant differences were found only for questions $6 e$ and $6 f$. For question $6 e$ there was a significant difference between the responses of auditors and users. For question $6 \mathrm{f}$ there was again a significant difference between the responses of managers and users.

Each group scored an average of more than 3 for each of the questions. This indicates that managers, auditors and users are on average all in favour of more environmental corporate reporting. The more strict percentage measure indicates that more than $50 \%$ of each group are in favour of each question, except one. Only $37 \%$ of managers were positive about third-party environmental audits.

More comprehensive disclosure of environmental matters is needed on a voluntary basis.

The the manager, auditor and user groups are on average all positive about more disclosure on a voluntary basis. $78 \%$ or more of each group agreed with this. The manager group seem to be most positive with $89 \%$ agreement, but they were not significantly more positive than auditors and users, according to Fisher's exact test at the $5 \%$ level. The reason why managers were so positive about this question may have been that they wanted to emphasize that environmental disclosures should be on a voluntary basis.

More comprehensive disclosure of environnental matters is needed on a compulsory basis.

The respondents of all three groups were in favour of more environmental disclosure on a compulsory basis. Although users appear on the face to be more positive, Fisher's exact test indicates that this is not significantly so. Questions 1 and 2 deal with the issue whether environmental reporting should be done on a voluntary or a compulsory basis. This was dealt with in theory in section 2.8 , where the conclusion was drawn that it should be made compulsory. According to the above responses, there would seem to be support for this view from various stakeholders. 
All environmental disclosure should be published as part of the annual financial statements or an addendum thereto to ensure accessibility.

The three groups were all in favour of the disclosure of environmental information in the annual financial statements. There were no significant differences between the responses of the different groups. The annual financial statements seem increasingly to be regarded as a source of information regarding all the activities of an organization.

More comprehensive environmental disclosure of a financial nature is needed.

The respondents in the various groups were equally in favour of environmental disclosure of a financial nature. Auditors seem to be more positive about financial information than managers, but the difference is not significant.

More comprehensive environmental disclosure of a non-financial nature is needed, such as descriptive information or information in physical units.

Respondents were also equally in favour of the disclosure of environmental information of a non-financial nature. Managers seem to be more positive about non-financial information disclosure than auditors, although the difference is again not significant.

The environmental policy of the organization.

The respondents felt that the environmental policy of an organization should be published as part of its annual financial statements. The three groups had no significant difference between their responses to this question. Such broad agreement also applied to the following items :

Measurable targets in physical units and in money amounts, where applicable, based on environmental policy, e.g. emissions:

Performance against environmental targets and comparative figures (previous year); 
Environmental costs (energy; waste handling, treatment and disposal, legal compliance, packaging; fines, rehabilitation; recycling, etc.) by category, charged to operating expenses during the period;

Independant third party attestation of all the aspects agreed to above.

The three groups agreed on the disclosure of third-party envirommental audits. Managers were, however, an exception, when the percentage agreed method was used. Users were significantly more in favour of this kind of reporting than managers. This is in line with the pattern that emerged throughout the analysis of the responses to both questionnaires. Managers seem to be reluctant to concede to the demand for information from users.

\section{Comparison with the results of a previous study}

The results of this empirical study were compared to those obtained in a previous study by De Villiers and Vorster (1995:44-66) by means of Fisher's exact test at the $5 \%$ level. For example, the auditors' responses to Question 1 were compared to the auditors' responses to the corresponding question in the De Villiers and Vorster study. This resulted in 33 tests, one for each of the three groups for each of the 11 questions.

Apart from Question 6f (see Table 2), the tests indicated no significant differences between the responses to the current study and the previous De Villiers and Vorster study. The above question deals with independent attestation of environmental reporting, and significant differences were found between the auditor, manager and the user categories.

The three groups were all significantly more in favour of reporting the results of independently performed environmental audits in the current study than in the previous De Villiers and Vorster study.

A smaller number of environmental items to be reported will apparently be more acceptable. 


\section{CONCLUSION}

It can be concluded from the empirical study that South Africans are willing to support more comprehensive environmental corporate reporting. even on a compulsory basis. Users of financial statements are in many cases more positive about this than the preparers and the auditors of these statements. Users. according to accountability theory, have the right to the information they require. Measures should therefore be taken to ensure that users of financial statements do get environmental information that they require too.

The accounting profession and the government are in a position to make more environmental corporate reporting compulsory by, for example, amending the fourth schedule to the Companies Act and/or introducing a new accounting standard. The items of environmental reporting in the appended questionnaire can be used as a point of departure for such amendments/statements.

The environment has long been overlooked as an important issue by business enterprises. This will become increasingly difficult in the future as the general public demands responsible environmental management practices from business. The right of environmentalists and other representative bodies to corporate information is also increasingly acknowledges, for example, by the South African Institute of Chartered Accountants (1997:04) and the Institute of Directors in Southern Africa (1994:2). These information rights should be entrenched by making environmental corporate disclosure compulsory. 


\section{APPENDIX A}

TO:

FAX NO:

All answers will be treared as strictly confidential and will be used for statistical purposes only QUESTIONNAIRE ON ENVIRONMENTAL REPORTING

- Please indicate the most accurate option by marking it with a cross
- Please indicate your own personal views

1. Do you own shares in a company?

2. Are you an employee of a company?

\begin{tabular}{|ll|}
\hline Yes & No \\
Yes & No
\end{tabular}

Willingness to support more comprehensive disclosure in the annual report

To what degree do you personally agree/disagree with the following staternents?

\begin{tabular}{|c|c|c|c|c|c|}
\hline$\widehat{S A}$ & - & Strongly Agree & $D$ & - & Disagree \\
\hline$A$ & & Agree & $S D$ & - & Strongly Disagree \\
\hline$U$ & - & Uncertain/Does & & & \\
\hline
\end{tabular}

1. More comprehensive disclosure of environmental matters is needed on a voluntary basis

2 More comprehensive disclosure of environmental matters is needed on a compulsary basis

3 All environmental disclosure should be published as part of the annual financial statements or an addendum thereto to ensure accesibility

4. More comprehensive environmental disclosure of a financial nature is needed

5. More comprehensive environmental disclosure of a non-financial nanure is needed

6. The following items should be disclosed by

\begin{tabular}{|l|l|l|l|l|l|}
\hline I & SA & A & U & D & SD \\
\hline 2 & SA & A & U & D & SD \\
\hline 3 & SA & A & U & D & SD \\
\hline 4 & & & & & \\
\hline 5 & SA & A & U & D & SD \\
\hline
\end{tabular}
organisations :

a) a descriptive overview of themajor environmental risks and impacts of the organisation

b) the environmental policy of the organisation

c) measurable targets in physical units and Rand amounts, where applicable, based on the environmental policy e.g. emissions

\begin{tabular}{|l|l|l|l|l|l|}
\hline a & SA & A & U & D & SD \\
\hline b & SA & A & U & D & SD \\
\hline c & SA & A & U & D & SD \\
& & & & & \\
\hline
\end{tabular}


d) performance against environmental targets and comparative figures (previous year)

e) environmental cost (energy; waste handling, treament and disposal; legal compliance; packaging; fines; rehabilitation; recycling; etc.) by

\begin{tabular}{|l|l|l|l|l|l|}
\hline$d$ & SA & A & U & D & SD \\
\hline e & SA & A & U & D & SD \\
\hline
\end{tabular}
category, charged to operating expenses during the period

f) independant third parry attestation of all the aspects agreed to above

\begin{tabular}{|l|l|l|l|l|l|}
\hline$f$ & SA & A & U & D & SD \\
\hline
\end{tabular}

Please send me a summary of the research results

\begin{tabular}{|l|l|}
\hline Yes & No \\
\hline
\end{tabular}




\section{REFERENCES}

1. BOGIAGES, G.H. and VORSTER, Q. (1993). Green Reporting in the Republic of South Africa. Pretoria: Department of Accounting, University of Pretoria.

2. CHUA, F.C. (1990). Externalities: One of the Most Difficult Aspects of Social Accounting. Palmerston North: Department of Accountancy, Massey University.

3. CANADIAN INSTITUTE OF CHARTERED ACCOUNTANTS. (1993, July). Reporting on Environmental Performance. Toronto, The Canadian Institute of Chartered Accountants, Discussion Paper.

4. CLULOW, D.A. (1991, April) Financial Reporting in an EnvironuentConscious World. Accountancy SA, 105-109.

5. DE VILLIERS, C.J. and VORSTER Q. (1995). More Corporate Environmental Reporting in South Africa? Meditari, 44-66.

6. ESTES, R. (1976). Corporate Social Accounting. New York, Wileyinterscience.

7. GRAY, R., OWEN, D. and MAUNDERS, K. (1987). Corporate Social Reporting: Accounting and Accountability. Englewood Cliffs, N.J., Prentice-Hall.

8. GRAY, R.H. (1993). Accounting for the Environment. London, Paul Chapman Publishing.

9. GRAY, R.H. (1994). Accounting, the Accountancy Profession and the Environmental Crisis (or can accountancy save the world?). Meditari, 151.

10. IJIRI, Y. (1975). Theory of Accounting Measurement. Sarasota, Florida: American Accounting Associarion.

11. INSTITUTE OF CHARTERED ACCOUNTANTS IN ENGLAND AND WALES. (1975). The Corporate Report. London: The Institute of Chartered Accountants in England and Wales, Discussion Paper.

12. INSTITUTE OF CHARTERED ACCOUNTANTS IN ENGLAND AND WALES. (1992). Business, Accountancy and the Environment: a Policy and Research Agenda. London, The Institute of Chartered Accountants in England and Wales, A Policy and Research Agenda. 
13. INSTITUTE OF DIRECTORS IN SOUTHERN AFRICA. (1994). The King Report on Corporate Governance. Johannesburg. The Institute of Directors in Southern Africa.

14. IJRI, Y. (1983). On the Accountability-based Conceptual Framework of Accounting. Journal of A Accounting and Public Policy, 2, $75-81$.

15. RABIE, M.A. (1992). Nature and Scope of Environmental Law. In: Fuggle, R.F. and Rabie, M.A. (eds.). Environmental Management in South Africa, Cape Town: Juta, 83-98.

16. RUBENSTEIN, D.A. (1992, March). Natural Capital and invisible Interests in Natural Resources. CPA Journal, 62(3), 28-33.

17. SANDBORG, V. (1993, Autumn). Producing an Annual Environnental Report. Journal of Environmental Regulation, 3(1), 57-68.

18. SAVAGE, A.A. (1994). Corporate Social Disclosure Practices in South Africa: A Research Note. Social and Environmental Accounting, 14(1), 2 4.

19. SOUTH AFRICAN INSTITUTE OF CHARTERED ACCOUNTANTS. (1990). Statement AC 000: Framework for the Preparation and the Presentation of Financial Statements. Johannesburg, The South African Institute of Chartered Accountants.

20. SOUTH AFRICAN INSTITUTE OF CHARTERED ACCOUNTANTS. (1997). Stakeholder Communication in the Annual Report. Johannesburg, The South African Institute of Chartered Accountants.

21. STEYN, J.0. and VORSTER, Q. (1994). Green Reponing in the Republic of South Africa - second edition. Pretoria: School of Accounting Sciences, University of Pretoria.

22. TOZER, L.E. (1992). The Accounting Implications of the New Zealand Resource Management Act 1991. Palmerston North, Department of Accountancy, Massey University.

23. UNITED NATIONS (1991). Accounting for Environmental Protection Measures. New York, UN CTC ISAR, Paper E/C. 10/AC.3/1991/5. 